Journal of Applied Veterinary Sciences, 6 (4): 46 - 50 (October, 2021).

ISSN: Online: 2090-3308, Print: 1687-4072

Journal homepage : https://javs.journals.ekb.eg

\title{
Comparative Study of Using Four Types of Avian Egg Yolk on Epididymal Sperms Chilled Storage in Awassi Rams (Ovis aries)
}

\author{
Faten Fadhel Mustafa ${ }^{1}$ and Uday Talat Naoman ${ }^{2 *}$ \\ Department of Surgery and Theriogenology, College of Veterinary Medicine, University of Mosul, Iraq. \\ *Corresponding Author, Uday T. Naoman, E-Mail: uday.naoman@uomosul.edu.iq
}

\begin{abstract}
The objective of the current experiment was to study the effect of different avian egg yolks (EYs) on rams epididymal sperms stored at $4{ }^{\circ} \mathrm{C}$. Sixteen pairs of testes $(n=32)$ were mature Awassi rams of about 1-4 years, slaughtered at Al-Sadoon abattoir, Mosul city were collected. The spermatozoa were collected from the tail of the epididymis by cutting and squeezing; after that, a total of $0.5 \mathrm{ml}$ of spermatozoa volume was diluted by using sodium citrate $2.9 \%$ and the volume was completed to $1 \mathrm{ml}$, then the sample was divided into four aliquots $(0.25 \mathrm{ml}$ for each one). The extender consisted of egg yolk (EY) $10 \%$ of four avian types (chicken, quail, duck, turkey), sodium citrate $2.9 \%$, fructose $2.4 \mathrm{gm}$, penicillin, and streptomycin (100.000 IU and $100 \mathrm{mg}$, respectively) in 100 distal water. Sperms individual motility, live sperm percentage, sperms abnormalities were checked at $0,72,144$ hours of storage. Results of the present study revealed that quail egg yolk improved sperms, individual motility, live sperm percentage with longer life span and reduce sperms abnormalities, followed by Turkey, chicken and duck EYs, respectively. Individual motility of the spermatozoa after $144 \mathrm{~h}$ of storage in quail EY extender were $(36.00 \% \pm 1.20)$, which higher than turkey EY $(32.30 \% \pm 1.30)$. However, these results were higher and significant $(\mathrm{P}<0.05)$ when compared with chicken EY extender $(24.60 \% \pm 2.30)$ and duck EY extender $(19.00 \% \pm$ 1.50). Similar results of quail and turkey EYs were manifested in the percentage of live spermatozoa, which were $(38.00 \% \pm 1.20),(33.30 \% \pm$ $1.30),(24.00 \% \pm 2.30)$, and $(19.90 \% \pm 1.50)$, respectively. The duck EY was significantly lower $(\mathrm{P}<0.05)$ when comparing the four egg yolks types after storage for $144 \mathrm{~h}$. In conclusion: we advise potentially using a quail or turkey EYs extender for the chilled storage for ram epididymal sperms.
\end{abstract}

Short communication:

DOI:https://dx.doi.org/10.21608/javs.2 $\underline{021.88532 .1096}$

Received :31 July, 2021.

Accepted :04 September, 2021.

Published in October, 2021.

This is an open access article under the term o Creative Commons Attribution 4.0 (CC International License. To view a copy of license, visit:

http://creativecommons.org/licenses/by/4.0/

J. Appl. Vet. Sci., 6 (4): $46-50$.

Keywords: Avian egg yolk, Epididymal sperm, Ram, Semen.

\section{INTRODUCTION}

In different animals and ruminants, Cauda epididymal sperm can be considered the only available source of male gametes for use in assisted reproductive programs (Mahdi et al., 2019). The cauda epididymis sperms could be recovered and stored in the same way as ejaculated spermatozoa (Abu $\boldsymbol{e t}$ al., 2016; Tunner et al., 2020). Demanding epididymal sperms at post mortem is essential in cases such as the unexpected death of genetically invaluable livestock males and endangered wild species (Ahmadi et al., 2020). Egg yolk (EY) is a unique component most widely used for semen storage, manipulation, dilution and preservation due to an extensive variety of elements that supported its effect on spermatozoal movement, viability and freezing (Al-any et al., 2016). However, its composition and content of Low-Density Lipoprotein (LDL), biochemical compounds, vitamins and unsaturated fatty acid were different according to the avian types, which may stimulus yolk efficiency throughout storage and protection against certain harmful effects for spermatozoa like cold shock, osmotic stress, sperm injuries, acrosomal defects and DNA integrity (Hermansson and Axner, 2007). Avian different types may provide different sources of egg yolks, so; the present study was designed to investigate the effect of four types of avian which were chicken, quail, turkey and duck EYs extenders for ram epididymal sperms individual motility, sperms live percentage and sperms abnormalities and storage in chilled temperature $\left(4 \mathrm{C}^{\circ}\right)$. 


\section{MATERIIALS AND METHODS}

\section{Animal samples and Study area:}

The study was carried out in the laboratory of Artificial Insemination, College of Veterinary Medicine, University of Mosul, Mosul, Iraq (N: $36^{\circ} 20^{\prime}$ 24": E: $043^{\circ}$ 07' 48") from September 2020 to November 2020. Sixteen pairs of testicles ( $\mathrm{n}=32$ testis/ semen samples ) from 16 mature Awassi rams aged between 1-4 years, slaughtered at Al-Sadoon abattoir were gained. The testes were transported in a cold box after washing with normal saline and antibiotics (penicillin-streptomycin) within $2 \mathrm{~h}$ after slaughtering.

\section{Epididymal Sperms collection:}

The spermatozoa were obtained by cutting and squeezing the cauda epididymis at ambient temperature in a Petri dish. The semen was collected in a $15 \mathrm{ml}$ glass graduated tube(Abu et al., 2016). All epididymis were gently excised from the testis. Sperms were undergone for macroscopic and microscopic examination under the light microscope for Individual motility, live sperms and sperms abnormalities percentages were estimated using red eosin $\% 5$ and nigrosine $\% 10$ stains. These examinations of sperm parameters were evaluated before dilution for all tests samples $(\mathrm{n}=32)$ and after dilution with avian egg yolks at $0,72,144$ hours.

\section{Sperms individual motility:}

Sperm individual motility was estimated according to Ferdinand et al., (2012). Briefly, $5 \mu \mathrm{l}$ of semen was assessed for motion under the microscope (40x) using coverslip and scored into 0100 grades.

\section{Sperm live percentage and abnormalities:}

A semen smear was prepared by mixing $2 \mu \mathrm{l}$ semen and $10 \mu \mathrm{l}$ Eosin-Nigrosin stain $(10 \mathrm{gm}$ of Nigrosin, $1.7 \mathrm{gm}$ Eosin and $2.9 \mathrm{gm}$ of sodium citrate in100 $\mathrm{ml}$ of distilled water). Sperm cells counted as alive that exclude strict exclusion of the stain (whitehead) and dead that stain eosin (redhead) against Nigrosin background (400x), calculating 200 sperms under the microscope after 2-3 minute slide dryness. The sperm's live percentage and abnormalities were estimated using the Eosin-Nigrosin staining as described by Uysal and Buck, (2007).

\section{Egg yolk extenders and semen dilution:}

A total of $0.5 \mathrm{ml}$ of spermatozoa volume was collected from the epididymis and diluted using sodium citrate $2.9 \%$ and completed to $1 \mathrm{ml}$, then divided into four aliquots $(0.25 \mathrm{ml}$ for each sample). Sperms were diluted in 1:10 (semen: extender) percentage ratio. Each type of egg yolk 10\% which perpetrated ( by drawing $10 \mathrm{ml}$ of yoks in sterile syringe) and adding to the extender, which consisted of egg yolk $10 \%$, sodium citrate $2.9 \%$, fructose $2.4 \mathrm{gm}$, penicillin, and streptomycin (100.000 IU and $100 \mathrm{mg}$, respectively) in total $100 \mathrm{ml}$ distal water (Naoman and Taha, 2010). The extender is added directly into the semen gradually to avoid a shock to the sperm. After 2-5 minutes of equilibration in the water bath, all extenders were examined for motility, live and dead sperm percentage, sperm abnormalities, and considered 0 hours, the samples in test tubes were moved in the refrigerator under $4 \mathrm{C}$ and sperms examined after $72 \mathrm{~h}, 144 \mathrm{~h}$, as affixed time under a light microscope.

\section{Statical analysis:}

The results of the present study were expressed as mean + standard error. One-way ANOVA was used to compare data using Sigma Stat (Jandel scientific software V3.1). Duncan's Multiple Range Test was used to assess if there were any significant variations at $\mathrm{P}(<0.05)$.

\section{RESULTS}

Data in Tables 1,2 and 3 shows the effect of different egg yolk types during different storage times on spermatozoa characteristics, including sperm individual motility, live sperms and sperm abnormalities percentage, at $0,72 \mathrm{~h}$, and $144 \mathrm{~h}$ of storage at $4^{\circ} \mathrm{C}$. In general, data show a well protective effect of quail EY on sperm characteristics followed by turkey EY, chicken and duck EYs, respectively after storage for $144 \mathrm{~h}$. Individual motility of the spermatozoa after $144 \mathrm{~h}$ of storage in quail $\mathrm{EY}$ extender was $(36.00 \% \pm 1.20)$, which is higher than turkey EY $(32.30 \% \pm 1.30)$.

Table 1: Percentage of Individual sperms motility of four avian egg yolks at 0,72 , and $144 \mathrm{~h}$ of storage in $4^{\circ} \mathrm{C}$.

\begin{tabular}{|c|c|c|c|c|}
\hline $\begin{array}{c}\text { Quail } \\
\text { EY }\end{array}$ & $\begin{array}{c}\text { Turkey } \\
\text { EY }\end{array}$ & $\begin{array}{c}\text { Duck } \\
\text { EY }\end{array}$ & $\begin{array}{c}\text { Chicken } \\
\text { EY }\end{array}$ & $\begin{array}{c}\text { Time } \\
\text { (hours) }\end{array}$ \\
\hline $\begin{array}{c}84.33 \pm \\
1.70^{\mathrm{a}}\end{array}$ & $\begin{array}{c}81.00^{\mathrm{a}} \\
2.40^{\mathrm{a}}\end{array}$ & $\begin{array}{c}80.30 \pm \\
1.70^{\mathrm{b}}\end{array}$ & $\begin{array}{c}87.33 \pm \\
1.50^{\mathrm{a}}\end{array}$ & 0 \\
$60.90 \pm$ & $58.30 \pm$ & $49.60 \pm$ & $56.60 \pm$ & 72 \\
$2.70^{\mathrm{a}}$ & $2.90^{\mathrm{a}}$ & $1.80^{\mathrm{b}}$ & $2.60^{\mathrm{a}}$ & 72 \\
& & & & \\
$36.00^{\mathrm{a}}$ & $32.30 \pm$ & $19.00 \pm$ & $24.60 \pm$ & 144 \\
$1.20^{\mathrm{a}}$ & $1.30^{\mathrm{a}}$ & $1.50^{\mathrm{c}}$ & $2.30^{\mathrm{b}}$ & 144 \\
\hline
\end{tabular}

$A b c$ : Different letters in same arrows indicate that the values are substantially different at $(\mathrm{P}<0.05)$. 
However, these results were higher and significant $(\mathrm{P}<0.05)$ when compared with chicken EY extender $(24.60 \% \pm 2.30)$ and duck EY extender $(19.00 \% \pm 1.50)$. Similar results of quail and turkey EYs were manifested in the percentage of live spermatozoa, which were $(38.00 \% \pm 1.20)$, $(33.30 \% \pm$ $1.30), \quad(24.00 \% \pm 2.30)$, and $(19.90 \% \pm 1.50)$, respectively. The duck EY was significantly lower $(\mathrm{P}<$ 0.05 ) when comparing the four egg yolks types after storage for $144 \mathrm{~h}$. Sperms abnormalities percentages were higher in duck EY extenders when compared with the other three egg yolks types, but with no significant differences between them after storage at 0,72 , and 144 hours.

Table 2: Percentage of live sperms in four avian egg yolks at 0,72 , and $144 \mathrm{~h}$ of storage in $4^{\circ} \mathrm{C}$.

\begin{tabular}{|c|c|c|c|c|}
\hline $\begin{array}{c}\text { Quail } \\
\text { EY }\end{array}$ & $\begin{array}{c}\text { Turkey } \\
\text { EY }\end{array}$ & $\begin{array}{c}\text { Duck } \\
\text { EY }\end{array}$ & $\begin{array}{c}\text { Chicken } \\
\text { EY }\end{array}$ & $\begin{array}{c}\text { Time } \\
\text { (hours) }\end{array}$ \\
\hline $\begin{array}{c}86.30 \pm \\
0.9^{\mathrm{a}}\end{array}$ & $\begin{array}{c}85.66 \pm \\
1.8^{\mathrm{a}}\end{array}$ & $\begin{array}{c}81.60 \pm \\
1.2^{\mathrm{a}}\end{array}$ & $\begin{array}{c}88.33 \pm \\
1.2^{\mathrm{a}}\end{array}$ & $0 \mathrm{~h}$ \\
$66.70 \pm$ & $66.00 \pm$ & $59.33 \pm$ & $64.00 \pm$ & \\
$2.4^{\mathrm{a}}$ & $2.9^{\mathrm{a}}$ & $1.8^{\mathrm{b}}$ & $2.1^{\mathrm{a}}$ & $72 \mathrm{~h}$ \\
$36.00 \pm$ & $32.30 \pm$ & $19.00 \pm$ & $24.00 \pm$ & \\
$1.2^{\mathrm{a}}$ & $1.3^{\mathrm{a}}$ & $1.5^{\mathrm{b}}$ & $2.3^{\mathrm{b}}$ & $144 \mathrm{~h}$ \\
\hline
\end{tabular}

$A b c$ : Different letters in same arrows indicate that the values are substantially different at $(\mathrm{P}<0.05)$.

Table 3: Percentage of sperms abnormalities in four avian egg yolks at 0,72 , and $144 \mathrm{~h}$ of storage in $4^{\circ} \mathrm{C}$.

\begin{tabular}{|c|c|c|c|c|}
\hline $\begin{array}{c}\text { Quail } \\
\text { EY }\end{array}$ & $\begin{array}{c}\text { Turkey } \\
\text { EY }\end{array}$ & $\begin{array}{c}\text { Duck } \\
\text { EY }\end{array}$ & $\begin{array}{c}\text { Chicken } \\
\text { EY }\end{array}$ & $\begin{array}{c}\text { Time } \\
\text { (hours) }\end{array}$ \\
\hline $1.06 \pm$ & $1.2 \pm$ & $2.3 \pm$ & $1.3 \pm$ & $0 \mathrm{~h}$ \\
$0.6^{\mathrm{a}}$ & $0.1^{\mathrm{a}}$ & $0.1^{\mathrm{a}}$ & $0.0^{\mathrm{a}}$ & \\
& & & & \\
$7.1^{\mathrm{a}}$ & $7.4 \pm$ & $9.1^{\mathrm{a}}$ & $7.9 \pm$ & $72 \mathrm{~h}$ \\
$0.1^{\mathrm{a}}$ & $0.2^{\mathrm{a}}$ & $0.1^{\mathrm{a}}$ & $0.2^{\mathrm{a}}$ & \\
$7.8^{\mathrm{a}}$ & $8.4 \pm$ & $9.9 \pm$ & $8.6 \pm$ & $144 \mathrm{~h}$ \\
$0.1^{\mathrm{a}}$ & $0.2^{\mathrm{a}}$ & $0.2^{\mathrm{a}}$ & $0.2^{\mathrm{a}}$ & \\
\hline
\end{tabular}

$A b c$ : Different letters in same arrows indicate that the values are substantially different at $(\mathrm{P}<0.05)$.

\section{DISCUSSION}

In the present study, after 144 hours of storage, quail EY extenders a significantly higher percentage of individual motility $(36.0 \% \pm 1.2)$ and live sperms $(38.0 \% \pm 1.2)$ followed by turkey EY $(32.3 \% \pm 1.3$ and $33.3 \% \pm 1.3$ ). However, individual motility values in chicken EY $(24.6 \% \pm 2.3)$ had significantly $(\mathrm{P}<0.05)$ higher than the duck EY $(19.0 \% \pm 1.5)$, same result by
(Saieed et al., 2018; Sunday et al., 2018; Durand et al., 2020) who reported quail EY extender are best for ram semen storage when they recorded $66.67 \%$ and $40.85 \%$ motile sperms after 48 and 72 hours of storage which higher than duck EY (39.28\%), turkey (38.00\%) and chicken $(36.85 \%)$, their result were attributed to composition of quail EY which has a lower ratio of polyunsaturated to saturated fatty acids compared to chicken EY (Choi et al., 2001).

Saturated fatty acids are more stable than unsaturated fatty acids counterparts, this may be give quail EY the advantage of better protection capability which recorded in this study were are agreement results reported by Trimeche et al., 1997 who reported a higher percentage of motile and progressively undulating spermatozoa using quail EY compared with chicken EY extender in jackass; they suggested that the reason of high percentage of motile sperms with quail egg yolk extender because higher content of phosphatidylcholine, less phosphatidylethanolamine (Sunday et al., 2018; El-Shamary et al., 2015).

Our findings are in accordance with previous reports in buffalo (Rawash et al., 2020; Waheed et al., 2012), in buck (Swelum et al., 2018), and bulls(Achi et al., 2017), these authors reordered that sperm cells were better protected in media containing duck or chicken EY than media containing quail EY. Furthermore, the present result disagrees with (Gholami et al., 2010) in rams and Akhter et al., (2010) in bulls who registered that the epididymal sperm improve in pigeon EY. The comparable fertilization and embryonic growth values showed that the ram semen improved in quail, goose, turkey, ostrich, pigeon, duck and chucker EYs and give better sperms motility, viability, lower acrosomal abnormalities, and enhance membrane integrity when compared with chicken EY (Ali $\boldsymbol{e t}$ al., 2013; Kulaksiz et al., 2010) which agreement with data of the present study.

Sperm abnormalities values after $72,144 \mathrm{~h}$ of storage time show no significant changes between all types of egg yolks, these data in line with (Saieed $\boldsymbol{e t}$ al., 2018) who registered $12.42 \%, 12.71 \%, 12.71 \%$ and $12.8 \%$ in quail, duck, turkey, and chicken EYs respectively with no differences between them.

There were discrepancies between the totals results between egg yolk types and animal types. The variations in sperm-membrane composition and egg yolk components of different avian species cause inconsistencies in the results of using egg yolks from different avian in semen extenders for different animals species-specific interactions may emerge (Bansal and Bilaspuri, 2017). 


\section{CONCLUSION}

The quail EY and turkey EY extender are better than chicken and duck EYs dilution of epididymal semen storage at $4 \mathrm{C}$ in Awassi rams.

\section{ACKNOWLEDGMENT}

The authors are grateful to the University of Mosul/college of Veterinary Medicine for providing facilities that helped improve the quality of this research; also, our great full to Dr. Khalida Younis for her assistant work for sperm cell preparation.

\section{Declaration of Conflicting Interests}

The authors revealed that there was no potential conflicts of interest.

\section{REFERENCES}

ABU, AH, KISANI, A. I., and AHMEN, T., 2016. Evaluation of cauda epididymides of Red Sokoto bucks. Veterinary world. (9): 1440-1444. DOI: $10.14202 /$ vetworld.2016.1440-1444.

ACHI, J.N., BARJE, P.P., REKWOT, P.I., ACHI, N. P., and ALPHONSUS, C., 2017. Effect of Four Different Avian Egg Yolks Tri- Sodium Citrate Extender On Storage Time Of Frisian X Bunaji Semen Characteristics. Journal of Animal Production Research. 29 (1):31-40.

AHMADI, E., NAZARI, H., DAVOODIAN, N., and KADIVAR, A., 2020. Feasibility of long-term ovine epididymal spermatozoa preservation in a simple extender containing egg yolk. Journal of Livestock Science and Technologies, 8(1): 59-67. DOI: 10.22103/j1st.2020.14524.1284.

Al-ANY, A.A.T., Al-TAMIMY, S.M.A., and AlMASHADANY, W.A.S., 2016. The Protective Effect of Egg Yolk From Different Avian Species of Awassi Ram Semen During Diluted in Tris-Egg Yolk Extender and Stored At $5^{\circ} \mathrm{C}$. Tikrit Journal of Agriculture Science, 16 (2): 116-120.

ALI, A.B.T., BOMBOI, G., and FLORIS, B., 2013. Replacing chicken yolk with yolks from other sources in ram semen diluents and their effects on fertility in vitro. Small Ruminant Research, 113:405-410. https://doi.org/10.1016/j.smallrumres.2013.01.017.

CHOI, SH, SONG, KT., and OH, HR., 2001. Cholesterol contents and fatty acid composition of a chucker, pheasant, guinea fowl and quail egg yolk. AsianAustralian Journal of Animal. Science, 14: 831-836. DOI: https://doi.org/10.5713/ajas.2001.831.

DURAND, M.P., RAMOS, L.A., ESPINOZA, R. R., DELGADO, R. A., MESTAS, R.R., GUZMAN, J.A., and GUERRA, U.P., 2020. Cryoprotective effect of the egg yolk of different species on the sperm quality of rams under conditions of the Peruvian Altiplano. Supernova, 10(1): 46-51. DOI. 10.18548/aspe/0008.07.

EI-SHARAWY, M. E., El-SEIFY, E. M., HUSSIEN, A.M., El-SHERBIENYM, and El-SHAMAA, I.S., 2015. Effect of Duck Egg Yolk on Cryopreservation and Fertility of Egyptian Buffalo Bull Semen.
International Journal of Agriculture Innovations and Research, 3(4): 2319-1473.

FERDINAND, N., THOMAS, T.T., AUGUSTAVE, K., HENERY, D.F., FERNAND, T., and ETIENNE, P.T., 2012. Effects of buck age, storage duration, storage temperature and diluent on fresh west African dwarf buck semen. Journal OF Reproduction Infertility, 3(3): 58-66. DOI: 10.5829/idosi.jri.2012.3.3.66216.

HERMANSSON, U., and AXNER, E., 2007. Epididymal and ejaculated cat spermatozoa are resistant to cold shock, but egg yolk promotes sperm longevity during cold storage. Theriogenology, (67): 1239-1248. https://doi.org/10.1016/j.theriogenology.2007.01.008

KULAKSIZ, R., CEBI, C., AKACY, E., and DASKIN, A., 2010. The protective effect of egg yolk from different avian species during the cryopreservation of Karayaka ram semen. Small Ruminant Research, 88: 12 - 15. https://doi.org/10.1016/j.smallrumres.2009.11.014.

MAHDI, S.W., AI-SHAMARY, M.S., and JAAFIR, Z.S., 2019. Role of spermatozoa in PH stability of caudal epididymis environment. Iraqi Journal of Veterinary Science, 33(1): 111-116. 10.33899/ijvs.2019.125511.1033.

NAOMAN, U. T. 2005. Study The effect of month and treatment with HCG hormone on quality and quantity of the semen before and After hemicastration in Iraqi Bucks - Nenava Governorate - MSc thesis. College of Veterinary medicine. University of Mosul. Mosul. Iraq.

RAWASH, Z., LIEL A., ANWER, A., and ElBADRY, D. A., 2020. Influence of Combination of Some Permeable Cryprotectants with Chicken and Duck Egg Yolks on Freezability and DNA Integrity of Buffalo Spermatozoa. Journal of Applied Veterinary Sciences, 5(3):49- 56. DOI: 10.21608/JAVS.2020.98371.

SAIEED, A.Y., MAHDI, Z.A., and IBRAHIM, A.A., 2018. Effect of addition from egg yolk of different avian to Tris extender on freezing semen traits of Awassi rams. Iraqi Journal of Agriculture Science, 49(1): 663-669. DOI: https://doi.org/10.36103/ijas.v49i4.76.

SUNDAY, A.A., TAIWO, O. J., OLUFEMI, A., and ABEL ADEYEMI, A., 2018. Effects of Egg Yolks from Different Avian Species on Boar Sperm Motility and Livability. Journal of Biology, Agriculture and Healthcare. 8(6):24-28.

SWELUM, A.A., SAADELDIN, I. M., AIANAZIA, M.B., AWADHA, H.B., AFIFIDI, M., and Al OWAIMER, A. N., 2018. Effects of adding egg yolks of different avian species to Tris glycerol extender on the post-thawing quality of buck semen. Animal Reproduction Science, 195: 345-354. https://doi.org/10.1016/j.anireprosci.2018.06.016.

TRIMECHE, A., ANTON, M., RENARD, P., GANDEMER, G., and TAITURIER, D., 1997. Quail egg yolk: a novel cryprotectant for the freeze preservation of Poitou jackass sperm. Cryobiology, 34: 385-393. https://doi.org/10.1006/cryo.1997.2009.

TUNNER, Z., CANISSO I., PODICO G., GARRET E., STEWART, J., and HENLEY, P., 2020. Cryopreservation of epididymal and Electro-ejaculated bull semen using liposome and egg yolk-based extender. Clinical Theriogenology, 12(1): 29-38.

UYSAL, O., and BUCAK. MN., 2007. Effects of oxidized glutathione, bovine serum albumin, cysteine and lycopene on the quality of frozen-thawed ram semen. 
Acta Veterinary Brno, 76: 383-90. Doi:10.2754/avb200776030383.

WAHEED, S., AHMAD, N., RAHMAN, N., RAHMAN, H., YOUNIS, M., and IQBAL, S., 2012. Evaluation of duck egg yolk for the cryopreservation of Nili-Ravi buffalo bull semen. Animal Reproduction Science. 131: 95-99. Doi:10.1016/j.anireprosci.2012.02.011.
How to cite this article:

Faten, Fadhel Mustafa and Uday, Talat Naoman, 2021. Comparative Study of Using Four Types of Avian Egg Yolk on Epididymal Sperms Chilled Storage in Awassi Rams (Ovis aries). Journal of Applied Veterinary Sciences, 6 (4): $46-50$.

DOI:https://dx.doi.org/10.21608/javs.2021.88532.1096 